\title{
The colder is warmer? A pre-study for wear trials of a reference clothing ensemble for EN 342 and EN 14058 for thermal manikin calibration
}

\author{
Kalev Kuklane*, Muhammad Salman Butt, Amitava Halder, Chuansi Gao \\ From 15th International Conference on Environmental Ergonomics (ICEE XV) \\ Portsmouth, UK. 28 June - 3 July 2015
}

\begin{abstract}
Introduction
Two sets of calibration ensembles for thermal manikins are available at present for EN 342 (and 14058). These 2 sets are not fully enough as: a) statistically, 2 points give an ideal regression line that does not need to be correct for extended range; b) they do cover an insulation range of only EN 14058 and the lower end of EN 342 - the insulation range of very cold and extremely cold exposures (below $-5{ }^{\circ} \mathrm{C}$ ), that is the main concern of EN 342, is not covered. The aims of the pre-test were to: a) settle the preliminary test conditions; b) test the equipment in extreme cold (down to $-40{ }^{\circ} \mathrm{C}$ ); c) suggest a metabolic rate for testing.
\end{abstract}

\section{Methods}

Ensemble C of Subzero project (cold store ensemble, SZC, [1]) was selected for testing. Three subjects participated in the pre-tests for wear trials. They were walking on a treadmill at $3.5 \mathrm{~km} / \mathrm{h}$. In Part $1 \mathrm{~S} 1$ was walking at $+20^{\circ} \mathrm{C}$ (with and without winter clothes) for 30 minutes, and at -2 and $-36{ }^{\circ} \mathrm{C}$, as well as $\mathrm{S} 2$ at $-38{ }^{\circ} \mathrm{C}$ (with $\mathrm{SZC}$ ) for 90 minutes. In Part 2 S3 was walking for 20-30 minutes at +10 (with and without winter clothes), $-10,-20$ and $-34{ }^{\circ} \mathrm{C}$ (with SZC). Bending stiffness (Pierce's test) of the sections of clothing outer layer was measured as a function of ambient temperature (used in Part 2). Different instruments and methods were used to analyse metabolic heat production from oxygen consumption $\left(\mathrm{VO}_{2}\right)$ : in Part 1 Metamax I and Metamax II and in Part 2 Metamax I and Douglas bag method. Other recorded parameters were body weight loss, heart rate, thermal (range from +4 to -4 ) and pain sensation (range from 0 to 3 ).

\footnotetext{
* Correspondence: kalev.kuklane@design.lth.se

Division of Ergonomics and Aerosol Technology, Department of Design Sciences, Faculty of Engineering, Lund University, Lund, Sweden
}

\section{Results}

Part 1: Participants were able to walk in extreme cold for 1.5 hours. Toes started feeling cold after $45 \mathrm{~min}$, pain was reported at around 50-55 min, and discomfort grew with time to the end of the exposure. Estimated metabolic rate (M) according to Givoni and Goldman [2] was $140 \mathrm{~W} / \mathrm{m}^{2}$. Estimated M from ISO 8996 for walking without load on level and even surface (mean of 3 and $4 \mathrm{~km} / \mathrm{h}$ ) was $153 \mathrm{~W} / \mathrm{m}^{2}$. M of S1 and S3 without winter clothes was around $160 \mathrm{~W} / \mathrm{m}^{2}, \mathrm{M}$ for them with SZC under warm and cold conditions about $180 \mathrm{~W} / \mathrm{m}^{2}$, and below $-30{ }^{\circ} \mathrm{C}$ for all about $200 \mathrm{~W} / \mathrm{m}^{2}$. Based on Part 2 it was ruled out that the treadmill speed could be affected by cold by counting belt rotations. The effect of cold on measured instrument values was ruled out, too, by comparing the results of different equipment that measured $\mathrm{VO}_{2}$.

\section{Discussion}

The metabolic rate seemed to increase at higher step rate (results from 1 subject only!). Would higher step rate strengthen clothing stiffness effect? It may be possible that the garment gets stiffer in cold and thus increases motion resistance. Previous research suggests that clothing stiffness may affect metabolic rate by $10 \%$ in addition to the protective clothing own effect (up to about $20 \%$, [3]).

\section{Conclusion}

The extreme cold may affect the instruments and measurement accuracy. However, these can be avoided by warming the sampling lines, removing ice if needed or using the Douglas bags. Cadence (step/min) may affect the results. If comparing the subjects and the manikin then the subjects should be requested to walk at the 
same frequency (45 double steps/min). Cold affects clothing stiffness. Most probably the effect is material dependent. Although the planned study was not performed, these pre-study results do define test parameters, and would provide possibility to run comparative tests with short notice.

Published: 14 September 2015

\section{References}

1. Anttonen $\mathrm{H}$, et al: Thermal manikin measurements - exact or not? International Journal of Occupational Safety and Ergonomics 2004, 10(3):291-300

2. Givoni B, Goldman RF: Predicting metabolic energy cost. Journal of Applied Physiology 1971, 30(3):429-433.

3. Dorman L, Havenith $G$ : The effects of protective clothing on energy consumption during different activities. European Journal of Applied Physiology 2009, 105(3):463-470.

doi:10.1186/2046-7648-4-S1-A161

Cite this article as: Kuklane et al:: The colder is warmer? A pre-study for wear trials of a reference clothing ensemble for EN 342 and EN 14058 for thermal manikin calibration. Extreme Physiology \& Medicine 2015 4(Suppl 1):A161.

\section{Submit your next manuscript to BioMed Central} and take full advantage of:

- Convenient online submission

- Thorough peer review

- No space constraints or color figure charges

- Immediate publication on acceptance

- Inclusion in PubMed, CAS, Scopus and Google Scholar

- Research which is freely available for redistribution

Submit your manuscript at www.biomedcentral.com/submit 